\title{
The President's Corner
}

By Frank Roy, President of the Saskatchewan Natural History Society

How soon will the editor of the Blue Jay be able to announce the publication of a new work entitled "The Birds of Saskatchewan"? It is 34 years since $H$. H. Mitchell published his "Catalogue of the Birds of Saskatchewan" in the Canadian Field-Naturalist. Since then we have learned much about the distribution of Saskatchewan birds and have added new species to the provincial list. Since 1924, regional lists have been published for Nipawin by Maurice Street (1942), for Emma Lake by Farley Mowait (1947), for DavidsonLast Mountain Lake by W. E. Clyde Todd (1947), for Yorkton by C. Stuart Houston (1949). for the Cypresis Hills and Flotten Lake by W. Earl Godfrey (1950), for Prince Albert National Park by J. Dewey Soper (1952), and for Somme by Ronald and Donald Hooper (1953).

Bird study in Saskatchewan was given a great impetus when Isabel M. Priestly edited the first issue of the Blue Jay in the fall of 1942. Mrs. Priestly founded better than she knew. Since that time the Blue Jay has become a journal widely respected in ornithological circles. One has but to scan any issue at random to find new sight or specimen records, in addition to articles on distribution and bird behaviour. A check of recent issues of the Blue Jay reveals for example, an account of the distribution of the Blue Goose in Saskatchewan; a list of records for the Surf Scoter; an account of the Lazuli Bunting nesting at Moose Jaw; a description of the dry-land nesting of the Western Grebe at Old Wives Lake; a situdy of the distribution of the European Starling in Western Canada; the first nesting record of the Caspian Tern for Saskatchewan ; new provincial records for the Golden-crowned Sparrow the Black Brant, and the Parula Warbler. What a wealth of information is being accumulated, awaiting sifting and organization for the new "Birds of Saskaitchewan."

Public interest in birds has been fostered by the building of the Provincial Museum. Also, in recent years, the staff at the Museum has been augmented, and Mr. Fred Bard and his assistants cover the province, fol- lowing up reports of new species, co lecting, photographing, recordin. bird songs, studying bird behaviou and contributing articles to Blue $\mathbf{J a}$.

As Stuart Houston pointed out reviewing the revised edition of th A.O.U. Check-list, the data for Sast atchewan contained therein is neith useful nor reliable, and the fault largely ours. To help correct this, th Society hopes to publish region lists from the Qu'Appelle Valle Carlton, Cumberland, the Coteau $\mathrm{r}$ gion in the elbow of the South Sast atchewan River, Siaskatoon, and $\mathrm{R}$ gina. But what is needed, above ar beyond these regional lists, is a wo combining these observations, tl Museum records and the observatios published in the Blue Jay since 194 The visitor to Saskatchewan has I single volume to which he can tus for information; the Saskatchews ornithologist. Would welcome a bo that described breeding ranges, mi ratory movements, and nesting habil In the new publication, we shou. attempt to give a complete bibli graphy of ornithological literatu pertaining to this province. The might also be a listing of provinci organizations interested in wildli and its conservation. Finally, the: might well be a place for an ornith logical history of the province, wri ten by someone like Stuart Houst who has taken such a great intere in our birds and birdmen, past ar present.

In the meantime, all membe should continue to send observatio: to the Blue Jay. Official records new, rare, or difficult-to-identi birds should preferably be supports by a specimen or photograph, but ol servations by several competent ol servers will also be given credenc Neither must we neglect day-to-di observations of common birdsspring arrival dates, nesting dat changes in numbers, fall movement unusual behaviour-which requi hundreds of observers from all ov the province, who are aible to wat the birds in a given area over a peric of years. The making of the "Bir, of Saskatchewan" will be an ente prise in which every member of t] Saskatchewan Natural History S ciety can play his part. 